\title{
Sintesis Alkohol Dari Limbah Nangka (Artocarpus heterophyllus) sebagai Campuran Bahan Bakar Minyak (biofuel)
}

\author{
Anita Fibonacci1 \\ 1Prodi Pendidikan Kimia UIN Walisongo Semarang \\ anitafibonacci@walisongo.ac.id
}

\begin{abstract}
ABSTRAK
Peningkatan akan kebutuhan energi terus meningkat seiring berjalannya waktu, namun peningkatan kebutuhan energy yang terjadi menimbulkan dampak semakin menipisnya pasokan ketersediaan bahan bakar fosil yang notabene merupakan sumber daya alam yang tak terbarui, disisi lain banyak limbah buah nangka (Artocarpus heterophyllus) yang sebenarnya berpotensi untuk diolah sebagai biofuel. Penelitian ini bertujuan untuk menghasilkan alkohol dari limbah nangka (Artocarpus heterophyllus) melalui proses fermentasi menggunakan saccharomyces cereviseae. Limbah buah nangka dimanfaatkan sebagai campuran bahan bakar minyak berbasis bahan dari biomassa (biofuel). Proses pembuatan alcohol dari limbah buah nangka diawali dengan pembuatan starter, medium fermentasi, proses fermentasi hingga mendapatkan alkohol dilanjutkan dengan proses pemurnian dengan cara destilasi. Analisis kadar alkohol dilakukan dengan metode berat jenis. Hasil penelitian menunjukkan bahwa alkohol yang dihasilkan dari limbah buah nangka (Artocarpus heterophyllus) adalah $20 \%$ dengan waktu fermentasi 12 hari.
\end{abstract}

Kata Kunci: biofuel, limbah nangka, alcohol

\begin{abstract}
Energy demand was increasing from time to time. Unfortunately, the increase in energy demand caused the depletion of supply to increase fossil fuel which is unrenewable resources. On the other hand, jackfruit waste (Artocarpus heterophyllus) has potential as a biofuel. This study was aimed to produce alcohol from jackfruit waste (Artocarpus heterophyllus) through a fermentation process using Saccharomyces cerevisiae. Jackfruit waste has been used as a biomass-fueled mixture (biofuel). The process of making alcohol from jackfruit waste began with a starter making, followed by making fermentation medium. The next step was the fermentation process until the alcohol was produced which is then purified through distillation. Analysis of alcohol content was carried out by the density method. The results showed that alcohol produced from jackfruit waste (Artocarpus heterophyllus) was $20 \%$ with a fermentation time of 12 days.
\end{abstract}

Keywords: biofuel, jackfruit waste, alcohol 


\section{Pendahuluan}

Dewasa ini, telah terjadi peningkatan akan kebutuhan bahan bakar secara signifikan dari hari ke hari (Alptekin, Canakci, Necati, Turkcan, \& Sanli, 2015). Sayangnya, peningkatan konsumsi bahan bakar ini, berbanding terbalik dengan pasokan dan ketersediaan sumber bahan bakar yang notabene masih diambil dari bahan bakar fosil (unrenewable resources) (Suirta, 2009; Hapsari \& Pramashinta, 2013) hal ini sepadan dengan pendapat dari Said, Wahid, \& Sabang, (2014) yang menyatakan bahwa pemenuhan kebutuhan akan energi bahan bakar di seluruh dunia berasal dari bahan bakar fosil, sedangkan bahan bakar ini merupakan SDA yang tidak dapat diperbaharui dan pasokannya di dunia sangat terbatas. sehingga berdampak pada semakin mahalnya harga bahan bakar minyak (BBM).

Para peneliti mulai mengembangkan bahan-bahan yang bisa menjadi sumber alternatif pengganti bahan bakar fosil, salah satunya adalah dengan mengembangkan bahan bakar yang berasal dari bahan pertanian seperti jagung, gula atau biomassa yang lain yang seringkali disebut sebagai biofuel (Irawan \& Arifin, 2012).

Biofuel banyak digunakan sebagai sumber energi alternatif adalah etanol. Etanol dihasilkan melalui proses fermentasi glukosa yang biasanya didapatkan dari hasil pertanian pangan. Penggunaan bahan pangan sebagai sumber energy alternatif ini dikhawatirkan akan menyebabkan adanya kompetisi akan kebutuhan makanan dan energy alternatif (Irawan \& Arifin, 2012), sehingga perlu adanya penelitian lebih lanjut untuk mengembangkan biofuel yang berasal dari bahan baku non pangan. Bahan baku non pangan ini salah satunya adalah limbah dari buah nangka (Artocarpus heterophyllus).

Direktorat Jendral Holtikultura Kementerian Pertanian (2013) melaporkan bahwa produksi buah nangka mengalami peningkatan produktivitas dari tahun 2011 654.808 ton, tahun 2012 sebesar 720.208 ton dan tahun 2013 sebesar 737.571. Nilai peningkatan produksi buah nangka diikuti dengan meningkatnya limbah dari buah yang lezat ini. Peningkatan limbah buah nangka, jika tidak dimanfaatkan, tentunya akan menyebabkan berbagai permasalahan lingkungan yang akhirnya berdampak buruk bagi kesehatan manusia. Di sisi lain, limbah dari buah nangka mengandung polisakarida. Merujuk dari hasil analisis kimia menurut Munadjim (1988) kandungan nutrien limbah nangka adalah karbohidrat 18,50\%, 68,90 \% air, lemak 2,11\%, fosfor $117 \mathrm{mg} / 100 \mathrm{gr}$, vitamin C 17,5 mg/100gr, protein 0,32\%, kalsium 715 mg/100gr, vitamin B 0,12 $\mathrm{mg} / 100 \mathrm{gr}$, besi $1,6 \mathrm{mg} / 100 \mathrm{gr}$, sehingga limbah nangka memungkinkan dimanfaatkan sebagai bahan baku pembuatan alkohol

18

Copyright @ 2019 WJC | ISSN 2621-5985 (online) | ISSN 2549-385X (print)

Volume 2, Nomor 1, 2019 
melalui proses fermentasi. Hal ini sepadan dengan hasil penelitian Graf \& Koehler (2000) yang mengungkapkan bahwa polisakarida dapat dimanfaatkan sebagai sumber gula yang murah dan mudah didapat.

Fermentasi menurut Winarno (1983) adalah reaksi oksidasi reduksi yang dialami suatu substrat organik dalam sistem biologi akibat adanya aktivitas mikroba yang menghasilkan senyawa lain dan energi. Salah satu substrat oganik yang dapat mengalami fermentasi adalah karbohidrat.

Karbohidrat monosakarida seperti glukosa, fruktosa, galaktosa, dan manosa dapat langsung diubah menjadi alkohol oleh mikroba yang terdapat dalam sel-sel ragi. Sedangkan karbohidrat disakarida seperti maltosa dan sukrosa harus dihidrolisis terlebih dahulu menjadi komponen sederhana monosakarida oleh enzim amylase (Dwidjoseputro, 1980).

Pada penelitian ini peneliti bermaksud memanfaatkan limbah limbah nangka sebagai sumber polisakarida yang digunakan untuk menghasilkan alkohol sehingga bisa dimanfaatkan lebih lanjut untuk menjadi alternatif tambahan dalam biofuel.

\section{Metode Penelitian}

\section{Alat dan Bahan}

Peralatan yang digunakan adalah alat-alat yang diperlukan dalam praktikum ini adalah set alat destilasi, erlenmeyer, toples tertutup, batang pengaduk, gelas kimia, labu ukur, mantel pemanas, piknometer, termometer, timbangan analitik, blender.

Bahan-bahan yang digunakan yaitu limbah nangka (Artocarpus heterophyllus), ragi roti, gula pasir, kalium metabisulfit $\left(\mathrm{K}_{2} \mathrm{~S}_{2} \mathrm{O}_{5}\right) \quad 0,5 \mathrm{mg} / 100 \mathrm{~mL}, \mathrm{NaOH} 0,1 \mathrm{~N}, \mathrm{HCl}$ $0,1 \mathrm{~N}$, aquades.

\section{Prosedur Kerja}

\section{Pembuatan Starter}

Limbah nangka sebanyak 1000 gram dicuci dan ditiriskan kemudian dipotongpotong. Potongan limbah nangka diblender dengan aquades sebanyak 1,5 L dengan suhu $90^{\circ} \mathrm{C}$ dan ditambahkan 440 gram gula. Kemudian masukkan $800 \mathrm{~mL}$ pulp nangka dalam toples dan ditambahkan $4 \mathrm{mg}$ kalium metabisulfit dan 2,4 gr ragi roti (saccharomyces cereviseae) lalu diaduk. Ditutup dengan kapas kemudian didiamkam selama 48 jam pada suhu kamar.

\section{Pembuatan Medium Fermentasi}

Mengambil pulp nangka (sisa pembuatan starter) ke dalam 4 Toples masing-masing sebanyak $100 \mathrm{ml}$ dan mengatur pH 1 sampai pH 4,5. Kemudian dipanaskan dengan suhu $60^{\circ} \mathrm{C}$ selama 3 menit.

\section{Proses Fermentasi}


Medium fermentasi (sisa pembuatan starter) ditambahkan dengan starter/bibit (v/v). Kemudian tutup dengan kertas aluminium. Difermentasi pada suhu kamar.

\section{Proses Pemurnian}

Pemurnian dilakukan dengan cara destilasi. Sampel hasil fermentasi dipisahkan dengan cara disaring. Kemudian sebanyak 100 $\mathrm{mL}$ filtrat dimasukkan ke dalam labu destilasi. Destilasi dilakukan pada rentang suhu $78^{\circ} \mathrm{C}-$ $100{ }^{\circ} \mathrm{C}$ hasil destilasi dianalisis kadar alkoholnya.

\section{Pengukuran Kadar Etanol dalam}

\section{Sampel}

a. Menentukan Volume Piknometer

Piknometer dibersihkan menggunakan aseton, kemudian dikeringkan dan ditimbang. Piknometer diisi dengan aquadest yang telah diketahui berat jenisnya . Menimbang piknometer yang telah diisi aquadest. Menghitung volume piknometer yang sebenarnya dengan rumus sebagai berikut:

$$
\mathrm{V}_{\text {piknometer }}=\frac{(\mathrm{b}-\mathrm{a}) \text { gram }}{\rho_{\text {aquades }}}
$$

\section{Keterangan:}

a = berat piknometer kosong

b = berat piknometer berisi aquades

c = berat piknometer berisi destilat

$\mathrm{V} \quad=$ volume piknometer

$\rho_{\text {destilat }}=$ berat jenis destilat

\section{b. Menentukan Berat Jenis Destilat}

20

Copyright (C) 2019 WJC | ISSN 2621-5985 (online) | ISSN 2549-385X (print)

Volume 2, Nomor 1, 2019
Mengisi piknometer dengan larutan hasil destilasi. Menimbang berat piknometer yang telah diisi larutan hasil destilasi. Menghitung berat jenis larutan hasil destilasi dengan rumus sesuai dengan persamaan (2).

$$
\rho_{\text {destilat }}=\frac{(c-a) \text { gram }}{V_{\text {piknometer }}}
$$

Keterangan:

$\mathrm{a}=$ berat piknometer kosong

$\mathrm{b}=$ berat piknometer berisi aquades

$\mathrm{c}=$ berat piknometer berisi destilat

$\mathrm{V}=$ volume piknometer

$\rho_{\text {destilat }}=$ berat jenis destilat

\section{HASIL DAN PEMBAHASAN}

Pohon nangka termasuk ke dalam suku Moraceae; nama ilmiahnya adalah Artocarpus heterophyllus. Pohon nangka umumnya berukuran sedang, sampai sekitar 20 m tingginya, walaupun ada yang mencapai 30 meter. Batang bulat silindris, sampai berdiameter sekitar 1 meter (Rizal, Sumarlan, \& Yulianingsih, 2013).

Metode yang digunakan untuk menetapkan kadar alkohol yang dihasilkan dari limbah buah nangka dalam penelitian ini adalah metode berat jenis. Berat jenis didefinisikan sebagai perbandingan massa dari suatu zat terhadap massa sejumlah volume air yang sama pada temperatur tertentu. Berat jenis larutan etanol dapat diukur dengan piknometer. Berat jenis larutan etanol semakin kecil, maka kadar etanol 
didalam larutan tersebut semakin besar (Mardoni, 2007). Dari data hubungan antara kadar alkohol dan berat jenis standar didapatkan persamaan regresi linier.

Tabel 1. Data hubungan antara kadar alkohol dan berat jenis

\begin{tabular}{ccc}
\hline No & $\begin{array}{c}\text { Kadar alkohol } \\
(\% \mathrm{v} / \mathrm{v})\end{array}$ & $\begin{array}{c}\text { Berat jenis alkohol } \\
(\mathrm{gr} / \mathrm{mL})\end{array}$ \\
\hline 1 & 5 & 0.9884 \\
2 & 10 & 0.9819 \\
3 & 15 & 0.9748 \\
4 & 20 & 0.9657 \\
5 & 25 & 0.9566 \\
\hline
\end{tabular}

Berdasarkan Tabel 1 dibuat kurva standar untuk mendapatkan persamaan regresi. Kurva standar disajikan dalam Gambar 1.

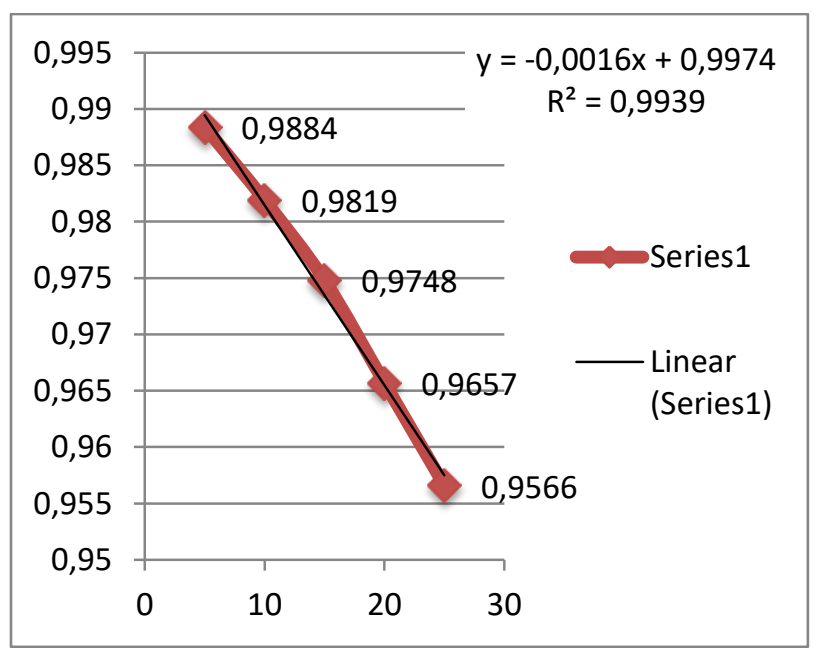

Gambar 1.

Kurva Standar Antara Kadar Alkohol dnegan

Berat Jenis Alkohol

Gambar 1 menggambarkan hubungan antara konsentrasi alkohol dengan berat jenis. Garis lurus pada kurva menunjukkan persamaan regresi $\mathrm{y}=-0,0016 \mathrm{x}+0,997$ yang digunakan untuk menghitung kadar alkohol pada sampel. Tanda negatif pada persamaan tersebut merupakan hubungan korelasi berbanding terbalik, yakni semakin besar kosentrasi alkohol maka semakin kecil berat jenis alkohol. Dari regresi tersebut massa jenis campuran larutan maksimal adalah 0,997 yaitu keadaan dimana kadar alkohol 0 \% dan air $100 \%$, saat harga massa jenis larutan lebih besar dari 0,997 maka harga X akan negatif.

Tabel 2. Hasil pengukuran sampel

\begin{tabular}{llc}
\hline No & $\begin{array}{l}\text { Berat jenis } \\
\text { alkohol } \\
(\mathrm{gr} / \mathrm{mL})\end{array}$ & $\begin{array}{c}\text { Kadar alkohol } \\
(\% \mathrm{v} / \mathrm{v})\end{array}$ \\
\hline & & \\
& & \\
& & \\
\hline
\end{tabular}

Proses fermentasi merupakan proses kimia yang berlangsung oleh adanya mikroorganisme yang mengkatalis reaksi. Jenis mikroorganisme yang dapat digunakan antara lain berupa ragi, bakteri, atau jamur untuk menghasilkan senyawa-senyawa seperti etanol, butanol, gliserol, asam asetat atau asam sitrat. Fermentasi oleh yeast, misalnya Sacharomyces cereviseae dapat menghasilkan etanol dan $\mathrm{CO}_{2}$ melalui reaksi sebagai berikut:

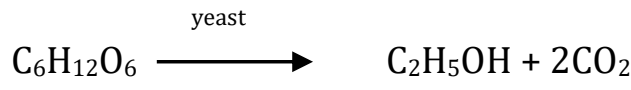




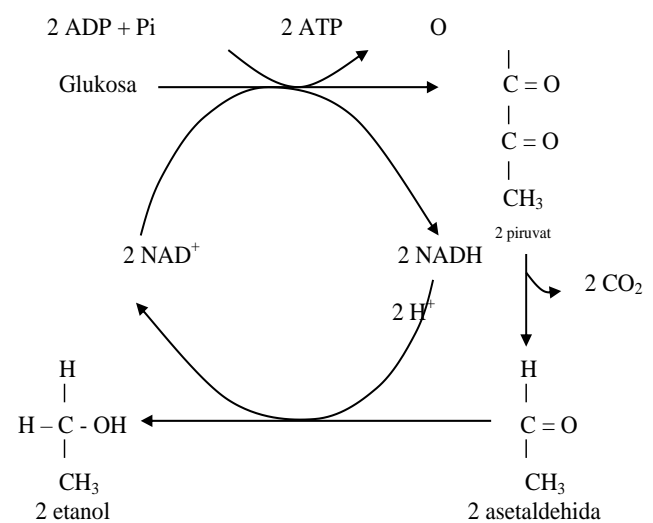

Gambar 2.

Proses Fermentasi Alkohol

Pada proses fermentasi alkohol tersebut, piruvat diubah menjadi etanol (etil alkohol) dalam dua langkah. Langkah pertama melepaskan karbon dioksida dari piruvat, yang diubah menjadi senyawa asetaldehida berkarbon-dua. Dalam langkah kedua, asetaldehida direduksi oleh NADH menjadi etanol.

Fermentasi menurut Winarno (1983) adalah reaksi oksidasi reduksi yang dialami suatu substrat organik dalam sistem biologi akibat adanya aktivitas mikroba yang menghasilkan senyawa lain dan energi. Salah satu substrat oganik yang dapat mengalami fermentasi adalah karbohidrat.

Karbohidrat monosakarida seperti glukosa, fruktosa, galaktosa, dan monosa dapat langsung diubah menjadi alkohol oleh mikroba yang terdapat dalam sel-sel ragi. Sedangkan karbohidrat disakarida seperti maltosa dan sukrosa harus dihidrolisis 22

Copyright (C) 2019 WJC | ISSN 2621-5985 (online) | ISSN 2549-385X (print) Volume 2, Nomor 1, 2019 terlebih dahulu menjadi komponen sederhana monosakarida oleh enzim amylase (Dwidjoseputro, 1980).

Wirahadikusuma (1985) menyatakan proses metabolisme karbohidrat menjadi etanol pada proses fermentasi alkoholik terbentuk melalui beberapa jalur metabolisme bergantung jenis mikroorganisme yang terlibat. Untuk Saccharomyces serta sejumlah khamir lainnya, etanol terbentuk melalui jalur Embden Meyernof Parnas (EMP) (Wirahadikusuma, 1985):

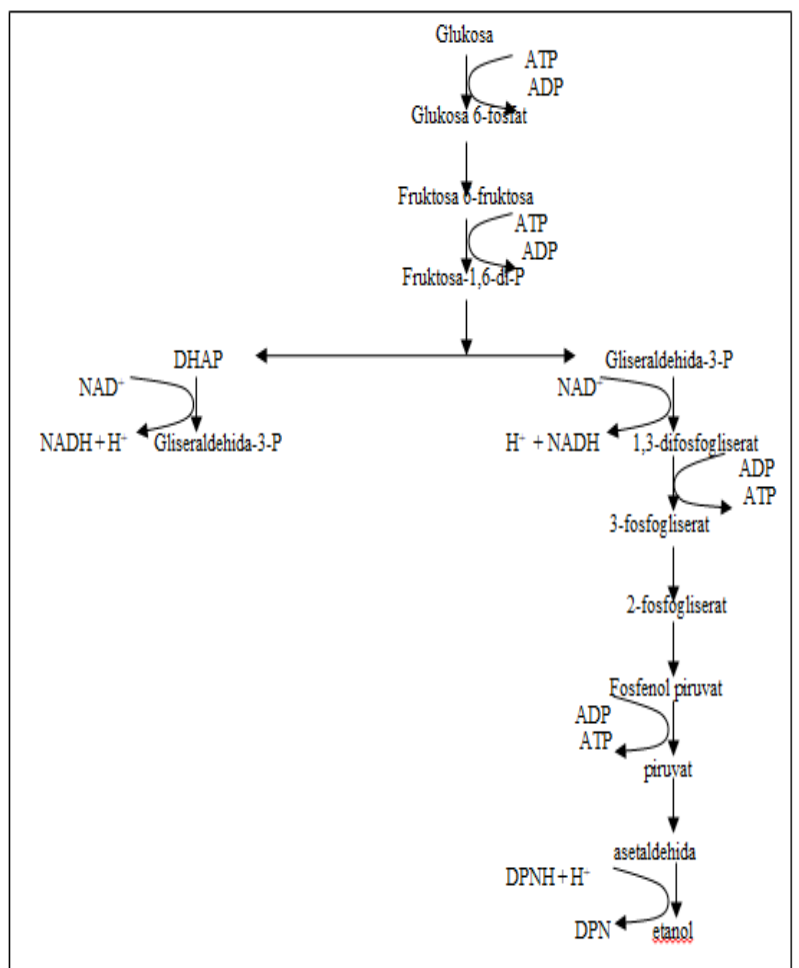

Gambar 2.

Jalur glikolisis EMP

Glukosa difosforilasi oleh ATP mula-mula menjadi D-glukosa-6 fosfat, kemudian mengalami isomerasi berubah menjadi Dfrukstosa-6 fosfat dan difosforilasi lagi oleh 
ATP menjadi D-fruktosa-1, 6 difosfat. Selanjutnya, D-fruktosa-1,6difosfat dipecah menjadi satu molekul D-gliseraldehid-3 fosfat dan satu molekul aseton fosfat. Langkah ketiga Dihidroksi aseton fosfat disederhanakan menjadi L-gliserol-3 fosfat oleh $\mathrm{NADH}_{2}$. Langkah keempat ATP melepaskan satu molekul fosfat yang diterima oleh gliseraldehid-3 fosfat yang kemudian menjadi D-1,3 difosfogliserat dan ADP. Langkah kelima D-1,3-difosfogliserat melepaskan energi fosfat yang tinggi ke ADP untuk membentuk D-3 fosfogliserat dan ATP. Langkah keenam D-3 fosfogliserat berada dalam keseimbangan dengan D-2 fosfogliserat. Langkah ketujuh D-2 fosfogliserat membebaskan air untuk menghasilkan fosfoenol piruvat. Langkah kedelapan ATP menggeser rantai fosfat yang kaya energi dari fosfoenolpiruvat untuk menghasilkan piruvat dan ATP. Langkah kesepuluh Piruvat didekarboksilasi menghasilkan asetaldehid dan $\mathrm{CO}_{2}$. Langkah terakhir akhirnya asetaldehid menerima hidrogen dari $\mathrm{NADH}_{2}$ menghasilkan etanol.

Faktor-faktor yang dapat mempengaruhi jumlah etanol yang dihasilkan fermentasi adalah mikroorganisme dan media yang digunakan, adanya komponen media yang dapat menghambat pertumbuhan serta kemampuan fermentasi mikroorganisme dan kondisi selama fementasi. Selain itu hal-hal yang perlu diperhatikan selama fermentasi adalah pemilihan khamir, kosentrasi gula, keasaman, ada tidaknya oksigen dan suhu.

Kriteria pemilihan khamir untuk produksi etanol menurut Desroaiser (1988) adalah mempunyai laju fermentasi dan laju pertumbuhan cepat, perolehan etanol banyak, tahan terhadap kosentrasi etanol dan glukosa tinggi, tahan terhadap kosentrasi garam tinggi. Khamir yang baik digunakan untuk menghasilkan etanol adalah dari genus Saccaromyces. Putra (2006) menyatakan kosentrasi glukosa yang dibutuhkan oleh sel Saccaromyces serevisae dalam fermentasi untuk menghasilkan kadar alkohol yang optimum sebesar $10 \%$.

$\mathrm{pH}$ optimal untuk pertumbuhan khamir/yeast adalah 4,0-4,5. jumlah asam yang terlalu tinggi dapat menyababkan denaturasi protein mikroba (Sa'id, 1987). Untuk pengaturan $\mathrm{pH}$ dapat digunakan $\mathrm{NaOH}$ untuk menaikkan dan asam sitrat untuk menurunkan. Pada pH 3,5 atau lebih rendah sedikit, fermentasi dapat berjalan dengan baik dan pada $\mathrm{pH}$ ini bakteri pembusuk akan terhambat (Desroiser, 1988).

Setiap mikroba membutuhkan oksigen yang berbeda-beda jumlahnya untuk pertumbuhan dan sel-sel baru dalam fermentasi. Ragi roti (saccharomyces cereviseae) akan melakukan fermentasi terhadap gula jauh lebih cepat dan baik pada keadaan anaerobik (Winarno,et.al, 1987) 


\section{A. Fibonacci}

Sa'id (1987) menyatakan suhu yang baik untuk proses fermentasi adalah dibawah $30^{\circ} \mathrm{C}$, makin rendah suhu fermentasi makin tinggi alkohol yang dihasilkan, karena pada suhu rendah fermentasi akan lebih komplit dan kehilangan alkohol karena terbawa oleh gas $\mathrm{CO}_{2}$ akan lebih sedikit. Biasanya fermentasi dilakukan pada suhu 25ํㅡ sampai $35^{\circ} \mathrm{C}$. Fermentasi dengan suhu $20^{\circ} \mathrm{C}$ menyebabkan kehilangan alkohol sebesar $0,65 \%$ sedangkan suhu $5^{\circ} \mathrm{C}$ alkohol akan hilang hanya 0,18\% (Walujo, 1984).

Faktor-faktor yang mempengaruhi fermentasi tersebut mempengaruhi kadar alkohol yang dihasilkan. Menurut praktikum Sugiarti (2007) dalam Astuti (2008), semakin lama waktu fermentasi maka semakin tinggi pula kadar alkohol yang dihasilkan dan semakin banyak dosis ragi yang diberikan maka kadar alkohol juga semakin tinggi. Kadar alkohol juga dipengaruhi oleh jumlah volume starter yang digunakan. Starter merupakan media untuk pertumbuhan bakteri. Starter dibuat dari adonan sampel yang diteliti sebagai prekayasaan pertumbuhan bakteri guna mendapatkan aktivitas bakteri yang optimal.

\section{SIMPULAN}

Berdasarkan hasil penelitian, maka dapat ditarik kesimpulan alkohol yang dihasilkan dari limbah buah nangka adalah $20 \%$ dengan waktu fermentasi 12 hari.

\section{DAFTAR PUSTAKA}

Alptekin, E., Canakci, M., Necati, A., Turkcan, A., \& Sanli, H. (2015). Using waste animal fat based biodiesels - bioethanol - diesel fuel blends in a DI diesel engine. FUEL, 157(1),245-254. https://doi.org/10.1016/i.fuel.2015.04.0 $\underline{67}$

Desroiser, N.W. (1988). Terjemahan Muchji Muljohardjo. Teknologi Pengawetan Pangan. Universitas Indonesia Press, Jakarta.

Direktorat Jendral Holtikultura Departemen Pertanian. (2013). Produksi Tanaman Buah di Indonesia Periode 2011 - 2013.

Graf, A., \& Koehler, T. (2000). OREGON CELLULOSE-ETHANOL STUDY: An evaluation of the potential for ethanol production in Oregon :Oregon

Hapsari, M. A., \& Pramashinta, A. (2013). Pembuatan Bioetanol Dari Singkong Karet (Manihot) Sebagai Upaya Mempercepat Konversi Minyak Tanah Ke Bahan Bakar Nabati. Jurnal Teknologi Kimia Dan Industri, 2(2), 240-245.

24

Copyright @ 2019 WJC | ISSN 2621-5985 (online) | ISSN 2549-385X (print)

Volume 2, Nomor 1, 2019 
Irawan, D., \& Arifin, Z. (2012). Hidrolisis Menggunakan Katalis Asam Synthesis Of Sugar From Organic Wastes Via Acid Catalyst. Reaktor, 14(2), 118-122.

Rizal, S., Sumarlan, S. H., \& Yulianingsih, R. (2013). Influence Sodium Bisulfite Concentration and Drying Temperature Toward. Jurnal Bioproses Komoditas Tropis, 1(2), 1-10.

Said, M., Wahid, A., \& Sabang, M. S. (2014). Synthesis of Bioetanol from Rice Straw ( Oryza sativa L ) By Fermentation. Jurnal Akademika Kimia, 3(November), 178182.

Suirta, I. W. (2009). Preparasi Biodiesel Dari Minyak Jelantah Kelapa Sawit. Jurnal Kimia, 3(1), 1-6.

Winarno, F.G. (1983). Enzim Pangan, PT Gramedia, jakarta.

Winarno, F. G, dan Srikandi. (1987). Kimia Pangan dan Gizi, Gramedia, Jakarta.

Wirahadikusumah, M., (1985). Biokimia : Metabolisme Energi, Karbohidrat, Dan Lipid. Institut Teknologi Bandung, Bandung. 